Izabela Łucjan

Maria Curie-Skłodowska University (UMCS) in Lublin

Faculty of Philosophy and Sociology

e-mail: izabela.lucjan@umcs.lublin.pl

\title{
Źródła i konsekwencje wzrostu elastyczności rynku pracy*
}

\section{The Sources and Consequences of the Growth of Labour Market Flexibility}

The transformation of the modern world of work towards the information society, knowledge society, have a rapid course. These transformations take on a global character, and the most of their consequences are negative. One of them is to base the employment process on the flexible solutions. Nowadays, neither the high level of education, nor the high competences are not enough to give confidence in finding employment. The contemporary labour market is characterised by unstableness, 'elusiveness' and, above all, flexibility. The challenge has become a flexible company, which employs only flexible workers within the framework of flexible forms of employment. Despite its universality, the concept of flexibility still remains inconsistent and vaguely defined.

Keywords: flexibility of employment, labour market, job changes, the post-Fordist work order

JEL Classification: J62, Z13

\footnotetext{
* Artykuł opublikowany w ramach projektu „Popularyzacja najnowszej wiedzy ekonomicznej wśród ludzi młodych" realizowanego z Narodowym Bankiem Polskim w ramach programu edukacji ekonomicznej.
} 


\section{Wprowadzenie}

Rynek pracy jako przedmiot badań i analiz teoretycznych obecny jest w naukach społecznych od ponad dwustu lat. Przemiany systemu gospodarowania, kształtowanie się stosunków pracy, rozwój techniki i technologii wpłynęły na ukształtowanie różnorodnych podejść do analizy oraz opisu sfery pracy i zatrudnienia. Zmieniał się także charakter otoczenia i jego wpływ na postawy i zachowania jednostek oraz relacje pomiędzy podmiotami i instytucjami rynku pracy. Postęp techniczny, pogłębiające się procesy globalizacyjne oraz niekorzystne zmiany w strukturze demograficznej, w szczególności krajów wysokorozwiniętych, stanowią obecnie najważniejsze wyzwania rozwojowe. Nie bez znaczenia pozostaje także kierunek zmian, w jakim podążają współczesne społeczeństwa, przechodząc od systemu przemysłowego, opartego na fordowskim stosunku pracy, w społeczeństwo poprzemysłowe. Jak pisze J. Gardawski:

wraz z nowa technologia i postępujaca globalizacja nastapity glębokie zmiany samej pracy i rynku pracy, obnizyło się zatrudnienie $w$ tradycyjnych działach przemystu, zmniejszyt się poziom koncentracji pracowników, wzrosła natomiast liczba pracowników sektora małych i średnich przedsiębiorstw oraz zwiększyła się rola sektora uslug, zwlaszcza prywatnych. Pojawity się nowe metody zarzadzania zasobami ludzkimi i nowe formy zatrudnienia, które zmienity charakter środowiska pracowniczego $(\ldots)^{1}$.

Te zmiany, charakterystyczne dla obecnego rynku pracy, koncentrują się głównie wokół elastyczności, która stała się symbolem nowoczesności form gospodarowania z jednej strony, z drugiej zaś -zamachem na dotychczasowy kształt stosunków pracy. Wizja elastycznej firmy opartej na elastycznym prawie pracy z elastycznymi (zdolnymi do szybkiego przekwalifikowania się i podnoszenia kwalifikacji) pracownikami oraz elastycznymi formami ich zatrudniania, zarówno pracowniczego, jak i niepracowniczego, traktowana jest już jako norma.

Podstawowym celem artykułu jest zwrócenie uwagi na zjawisko elastyczności jako na jedną z podstawowych kategorii pojęciowych, przy pomocy której opisywanych jest szereg zjawisk mających miejsce na współczesnym rynku pracy. Pomimo iż jest on zależny od wielu różnorodnych zmiennych demograficznych, społecznych, psychologicznych, czy też ekonomicznych, mających wymiar zarówno mikroekonomiczny (związany z indywidualnymi cechami danego przedsiębiorstwa bądź pojedynczej osoby poszukującej zatrudnienia), jak i makroekonomiczny (wynikający z powiązania tego rynku z innymi sferami funkcjonowania systemu gospodarczego), to istotne znaczenie ma silne powiązanie ich z elastycznością.

\footnotetext{
${ }^{1}$ Polacy pracujacy a kryzys fordyzmu, red. J. Gardawski, Wydawnictwo Naukowe SCHOLAR, Warszawa 2009, s. 55.
} 


\section{Przemiany pracy i rynku pracy}

Współczesne przemiany kształtujące rzeczywistość społeczno-ekonomiczną mają wyjątkowo dynamiczny charakter. Dokonujące się zmiany, chociażby te związane wyłącznie ze sferą pracy i zatrudnienia, będące efektem rozwoju techniki i technologii, zanikania starych oraz pojawiania się nowych zawodów i profesji oraz przechodzenia w kierunku społeczeństwa opartego na wiedzy, sprzyjają kształtowaniu się trudnych do przewidzenia konsekwencji owych procesów. Za P. Druckerem do opisu tych zmian można użyć pojęcia „turbulentny”", czyli trudny do przewidzenia, będący źródłem licznych zagrożeń stabilności funkcjonowania poszczególnych rynków, w tym szczególnie rynku pracy. Rynek pracy należy uznać za „trudny” ponieważ:

(1) narasta podaż pracy nisko-wykwalifikowanej, przy niskim na nią popycie,

(2) brakuje pracowników o wysokich kompetencjach zawodowych,

(3) wraz z rozwojem i upowszechnianiem się technologii informacyjnych znikają etaty dla pracowników umysłowych wykonujących jedynie prace rutynowe, w tym także pracowników szeroko rozumianych urzędów i administracji,

(4) wzrasta zainteresowanie pracownikami wysoko wykwalifikowanymi, elastycznymi, umiejącymi szybko dostosować się do zmieniających warunków, świadomych tego, że zdobyty i wyuczony zawód nie stanowi gwaranta stałego zatrudnienia,

(5) odchodzi się od wąskich specjalności w kierunku wyższych kwalifikacji i lepszego przygotowania ogólnego,

(6) następuje pomieszanie się pracy fizycznej z pracą umysłową, a także wzrost znaczenia pracy menedżerów, inżynierów i średniego personelu dozoru technicznego,

(7) odchodzi się od pracy na całe życie w jednym zawodzie, upowszechniania się model kariery skokowej, a wiedza bywa postrzegana jako kolejny czynnik produkcji.

A. Schaff traktuje te przemiany w sferze pracy jako jedno z czterech, obok zagrożenia wybuchem wojny, niebezpieczeństwa demograficznego i kwestii ochrony środowiska, zagrożeń współczesnego świata ${ }^{3}$.

Dokonujące się przeobrażania są również efektem zmian w charakterze pracy jako zjawiska społeczno-gospodarczego. Powszechna jej tymczasowość, nowe relacje, a także wirtualizacja są spowodowane faktem, że w turbulentnym otoczeniu przetrwać mogą jedynie te jednostki, organizacje i instytucje, które są w stanie szybko dostosować się do przekształcającego się otoczenia. Dotychczasowe, stałe zatrudnienie staje się zjawiskiem coraz rzadszym, pozostaje ono bowiem w jawnej sprzeczności z pożądaną dynamiką zmian. Jak twierdzi F. Fukuyama, obecny charakter rynku pracy determinowany jest poprzez istotę przemian cywilizacyjnych,

\footnotetext{
${ }^{2}$ P. Drucker, Społeczeństwo pokapitalistyczne, Wyd. Naukowe PWN, Warszawa 1999.

${ }^{3}$ A. Schaff, Rozważania na koniec wieku [w:] Człowiek i świat. Współczesne dylematy. Rozmowy Zdzisława Słowika, Biblioteka „Res Humana”, Warszawa 2007, s. 91-92.
} 
a przejście od epoki industrialnej do informatycznej jest dla ludzkości przemianą równie doniosłą, jak kiedyś przejście od pasterstwa do rolnictwa, czy później od rolnictwa do rewolucji przemysłowej ${ }^{4}$. $\mathrm{Z}$ charakteru dokonujących się przemian wyłania się nowy obraz pracy, która będzie coraz bardziej twórcza, a wraz z nią ujawnią się nowe wymagania stawiane pracownikom. Dotyczą one głównie tzw. kompetencji miękkich odnoszących się do cech osobowościowych, temperamentu, preferowanych postaw i zachowań, podejmowanych inicjatyw, umiejętności komunikacji, itp. W związku z tym na pierwszy plan wysuwają się psychologiczne aspekty pracy. Od pracowników oczekuje się, że będą oni skutecznie sterowali tym otoczeniem, kreatywnie je zmieniając.

\section{Elastyczność rynku pracy - blaski i cienie}

Okres lat dziewięćdziesiątych XX wieku to czas poszukiwań nowych rozwiązań na rynku pracy. Wśród proponowanych strategii na plan pierwszy wysuwają się te, które opierają się na elastyczności. Zjawisko to można rozumieć jako zdolność lub łatwość przystosowania się jakiegoś stanu (układu) do nowych, zmieniających się warunków ${ }^{5}$, jako przeciwieństwo sztywności, mające wpływ na wzrost efektywności funkcjonowania systemu'.

Pierwotnie pojęcie elastyczności odnosiło się do opisu zjawisk w naukach biologicznych ${ }^{7}$, a obecnie coraz częściej jest wykorzystywane także i w naukach społecznych. Na stałe w opisie rzeczywistości zaistniały: elastyczna gospodarka, elastyczna organizacja, elastyczny pracownik, elastyczny czas pracy, elastyczne formy umów, elastyczne miejsca pracy, a nawet elastyczne kompetencje i umiejętności oraz coraz częściej opisywane elastyczne społeczeństwo. Pomimo trwałego już miejsca w dyskursie publicznym, elastyczność to nadal pojęcie bardzo niespójnie i nieostro rozumiane. Na fakt ten zwrócił uwagę między innymi R. Reich, Sekretarz Stanu do Spraw Zatrudnienia USA, który w 1994 roku, mówiąc o elastyczności rynku pracy, podkreślił dużą pojemność słowa i jego małą klarowność stwierdzając: Nie wiem, co oznacza słowo "elastyczność« (flexibility). Rzadko w dyskusjach międzynarodowych sens pojęcia przechodzi tak bezpośrednio od niejasności do braku wszelkiej treści $(\ldots)^{8}$.

Niejasności definicyjne przyczyniają się do istnienia różnorodnych ocen elastyczności. Wynikać to może z faktu, że „zaistnienie” elastyczności we wszystkich sferach aktywności człowieka powoduje przede wszystkim wzrost niepewności

\footnotetext{
${ }^{4}$ F. Fukuyama, Wielki wstrzas. Natura ludzka a odbudowa porzadku spolecznego, Bertelsman Media, Warszawa 2000, s. 59.

${ }^{5}$ A. Stabryła, Modelowanie elastycznych rozwiazań struktury organizacyjnej, „Zeszyty Naukowe Akademii Ekonomicznej w Krakowie" 1990, nr 323, s. 6-7.

${ }^{6}$ M. Gableta, Czlowiek i praca w zmieniającym się przedsiębiorstwie, Wyd. Akademii Ekonomicznej im. Oskara Langego we Wrocławiu, Wrocław 2003, s. 117.

${ }^{7}$ Pojęciem tym określano zdolność drzew do ustępowania przed siłą wiatru, a także powracania do stanu wcześniejszego (określenie z XV wieku).

${ }^{8}$ R. Reich, Wystapienie na Międzynarodowej Konferencji Pracy w Genewie [za:] M. Kabaj, Czy rynek pracy $w$ Polsce jest mato elastyczny?, www.mg.gov.pl.
} 
i nieprzewidywalności jego działań. Dążenie do elastyczności stosunków pracy, bez odpowiedniego zaplecza strategicznego stało się główną i bezpośrednią przyczyną powstania i dynamicznego wzrostu światowego prekariatu ${ }^{9}$. Jak pisze G. Standing:

\begin{abstract}
pęd do elastyczności pracy (...) to proces wtórnego utowarowienia, który czyni prace uktadem coraz bardziej podatnym na popyt i podaż, mierzalnym za pomoca ceny, czyli płacy. Taki stan rzeczy oznacza erozje wszystkich siedmiu rodzajów bezpieczeństwa (bezpieczeństwa na rynku pracy, bezpieczeństwa zatrudnienia, bezpieczeństwa miejsca pracy, bezpieczeństwa pracy, bezpieczeństwa reprodukcji umiejętności, bezpieczeństwa dochodu, bezpieczeństwa reprezentacji) związanego z praca ${ }^{10}$.
\end{abstract}

Zjawisko elastyczności w świecie pracy rozwija się niezwykle szybko, generując liczne konflikty i problemy społeczne. Elastyczne formy pracy i zatrudnienia bywają bowiem wykorzystywane przez pracodawców do obniżania zabezpieczeń społecznych, a to wywołuje opór pracowników przed regulacjami umożliwiającymi stosowanie takich form pracy. Jednym $\mathrm{z}$ aspektów elastyczności jest coraz częstsze sięganie po tymczasowe formy pracy, które pozwalają firmom na szybką zmianę zatrudnienia, co z kolei pozwala na łatwiejsze zaadaptowanie do zmiennych warunków otoczenia. Coraz częściej mamy do czynienia z zadaniowym charakterem pracy, gdzie praca nastawiona jest na konkretny projekt, a nie na wielość i różnorodność zadań, co z kolei skutkuje mniejszą ciągłością zatrudnienia. Elastyczność implikuje większą ilość pracy-dla-zatrudnienia: zacieranie się granic między miejscem pracy, przestrzenią domową i publiczną oraz przechodzenie od kontroli bezpośredniej do zróżnicowanych form kontroli pośredniej, w której stosuje się bardziej wyszukane mechanizmy technologiczne. Sytuacja taka sprzyja rozwojowi pracy na odległość, która rozbija zespoły pracownicze, a w konsekwencji prowadzi do rosnącej izolacji pracowników. Wirtualne miejsca pracy stają się coraz bardziej powszechne, ,zdalne pulpity” i zapisywanie plików w „chmurach” pozwala na przenoszenie ustawień i plików do dowolnego komputera, bez względu na miejsce i czas ${ }^{11}$.

Efektem tych zmian są również przekształcenia w obrębie zawodów oraz możliwości kontrolowania i rozwijania własnego potencjału zawodowego przez pracowników. Spowodowało to także znaczące utrudnienia w definiowaniu własnej ścieżki kariery zawodowej przez pracowników. Nie tylko w znaczeniu przejścia z kariery o hierarchicznej strukturze opartej na awansie do kariery horyzontalnej, ale także z uwagi na wielość i różnorodność doświadczeń zawodowych determinu-

\footnotetext{
${ }^{9}$ Termin ,,prekariat” został po raz pierwszy użyty przez francuskich socjologów w latach osiemdziesiątych w celu określenia grupy pracowników tymczasowych i sezonowych; inne rozumienia tego terminu to: określenie osób z niskim dochodem, bądź wykonujących prace dorywcze, ale także potraktowanie prekarii jako normalnego stanu życia (Włochy); pracownicy tymczasowi oraz bezrobotni niemający nadziei na społeczna integrację (Niemcy); synonim , pracujących biednych” (Japonia). Cf. G.V. Standing, Prekariat. Nowa niebezpieczna klasa, PWN, Warszawa 2014, s. 47.

${ }^{10}$ Ibidem, s. 85.

${ }^{11}$ Ibidem, s. 99.
} 
jących rozmaitość i mnogość ścieżek rozwoju zawodowego. Posiadanie kwalifikacji do wykonywania określonego zawodu to jedno. Inną kwestię stanowią dodatkowe kompetencje i umiejętności, które mieć powinien współczesny pracownik. Podstawowe pytania, wokół których koncentrują się problemy aktywności zawodowej, dotyczą tego, co jest przydatne oraz jaki rodzaj kompetencji i umiejętności da pracownikowi przewagę konkurencyjną na rynku. Według G. Standinga:

niepewność jest większa w przypadku konkretnych umiejętności zawodowych. Można spędzić lata, nabywając różne kwalifikacje i nagle odkryć, że staty się one przestarzałe bądź niewystarczajace. (...) Rodzi się tu paradoks: im bardziej wykwalifikowana praca tym bardziej prawdopodobne, że nastapi jakieś , udoskonalenie” wymagajace ,przekwalifikowania”. Można to ująć jeszcze inaczej: im wyższe sa twoje kwalifikacje, tym bardziej prawdopodobne, że zacznie ci brakować umiejętności $w$ dziedzinie twoich kompetencji. Być może należałoby nazwać to zjawisko , dewaluacja umiejętności”. Nie chodzi już o to by być tak dobrym, jak byto się wczoraj, ale by być tak dobrym, jak powinno się być jutro. (...) Nie tworzy to klimatu sprzyjającego rozwojowi potencjału ludzi, ale raczej taki, w którym dominuja nieustanny stres i poczucie niespetnienia ${ }^{12}$.

\section{Bezpieczeństwo w społeczeństwie elastyczności}

Jedną z licznych koncepcji poświęconych funkcjonowaniu współczesnego społeczeństwa jest analiza A. Giddensa ${ }^{13}$, który to wskazuje na jego cztery podstawowe cechy: zaufanie, ryzyko, nieprzejrzystość i globalizację. Szczególne znaczenie dla niniejszej analizy mają pojęcia ,zaufania” i ,ryzyka”. Jest to efektem wszechobecności w życiu człowieka nowoczesnego ,abstrakcyjnych systemów”, których zasady mają charakter nie do końca zrozumiały dla ,zwykłych” ludzi, a które są z kolei niezbędne dla codziennego funkcjonowania i przyszłego rozwoju społecznego.

Pojęcie zaufania można obecnie z całą stanowczością przenieść do sfery pracy i zatrudnienia, gdzie z jednej strony odnaleźć można pracowników posiadających określoną wiedzę i umiejętności, gotowych poświęcić swój czas na wykonywanie określonych czynności, z drugiej - pracodawców zapewniających określone miejsce i warunki pracy, potencjalne możliwości rozwoju i awansu, oferujących zatrudnienie. Zawierając umowę na określonych warunkach, każda ze stron przyjmuje ciche założenie, że druga strona wykaże najwyższe zaangażowanie i będzie wywiązywać się z przyjętych warunków umowy, przestrzegania prawa pracy i niepisanych zasad współżycia społecznego w miejscu pracy. Podziat pracy, choć jest źródłem bogactwa, w większym stopniu uzależnia nas od tego, czy inni będa w stanie wywiazać się ze swoich zobowiązań ${ }^{14}$.

\footnotetext{
12 Ibidem, s. 251.

13 A. Giddens, Socjologia, WN PWN, Warszawa 2005.

${ }^{14}$ L. Clarke, J. Short, Social organization and risk: some current controversies, ,Annual Review of Sociology" 1993, vol. 19, s. 384.
} 
Kolejnym, równie istotnym elementem charakterystycznym dla społeczeństwa późnej ponowoczesności jest pojęcie ryzyka. Oznacza ono niepewność co do skutków podejmowanych działań lub niemożliwe do określenia prawdopodobieństwo negatywnych skutków niezależnych od woli jednostki. Znaczący wkład w zdefiniowaniu znaczenia i roli jaką odgrywa ryzyko we współczesnym świecie ma koncepcja U. Becka ${ }^{15}$. Paradygmat społeczeństwa ryzyka wiąże się z pytaniem: jak w zaawansowanych procesach modernizacji można uniknąć systematycznie produkowanego ryzyka i zagrożeń, jak je skanalizować, zbagatelizować, udramatyzować, żeby nie przeszkodziły procesowi modernizacji, żeby nie przekroczyły granic „tego, co dopuszczalne".

Z założenia elastyczność i bezpieczeństwo nie powinny być pojęciami wykluczającymi się wzajemnie, ale wspierającymi. Wynika to między innymi z faktu, że przy tak dynamicznie zmieniającym się otoczeniu rynku pracy, pracownicy muszą zdać sobie sprawę z tego, że praca/zatrudnienie nie są im raz na zawsze dane. Stąd pojęcie bezpieczeństwa, jako gwaranta w momencie zmiany pracy, przechodzenia $\mathrm{z}$ jednej do drugiej, w okresie koniecznego dokształcania ${ }^{16}$. Zintegrowana strategia równoczesnego zwiększania elastyczności i bezpieczeństwa pracy zasadza się na płynnie przebiegających zmianach w życiu zawodowym jednostki: zakończenie okresu nauki i rozpoczęcie aktywności zawodowej, zmiana pracy, podjęcie pracy po okresie bezrobocia lub braku zatrudnienia, przejście na emeryturę. Nie ogranicza się do zwiększenia możliwości przedsiębiorstw w zakresie zatrudniania i zwalniania pracowników, ani nie oznacza, że umowy na czas określony są już niepotrzebne. Chodzi tu o możliwości zmiany pracy na lepszą, awansu i optymalnego rozwoju indywidualnych zdolności ${ }^{17}$.

Wpływ pracy na losy ludzkie jest od wieków powszechnie potwierdzany i wysoko ceniony. To, co szczególnie istotne to potrzeba innego niż dotychczas traktowania powinności człowieka, takich jak: ogólnoludzkie, rodzinne, zawodowe, społeczne i edukacyjne. W celu przeciwdziałania negatywnym zmianom w sferze pracy i zatrudnienia, niezbędne jest zdefiniowanie odpowiednich regulacji, które byłyby odpowiedzią na najważniejsze problemy współczesnego świata. Ważną kwestią pozostaje zapewnienie reprezentatywności wszystkich grup uczestników rynku pracy, prostota procedur reprezentacji oraz równy i powszechny dostęp do informacji. Postulowana elastyczność pracy ma swoje ramy, a nawet granice. Ważne jest, aby w reformach deregulacyjnych nie pójść za daleko i nie doprowadzić do chaosu.

\footnotetext{
${ }^{15}$ U. Beck, Społeczeństwo ryzyka. W drodze do nowoczesności, Wydawnictwo Naukowe SCHOLAR, Warszawa 2004.

${ }^{16}$ Flexicurity Pathways. Turning hurdles into stepping stone, Report by the European Expert Group on Flexicurity, Brussels, June 2007, s. 11.

${ }^{17}$ Komisja Wspólnot Europejskich, Komunikat Komisji do Parlamentu Europejskiego, Rady Europejskiego Komitetu Ekonomiczno-Społecznego i Komitetu Regionów, Wspólne zasady wdrażania modelu Flexicurity, Bruksela 27.06.2007.
} 


\section{Konkluzje}

Praca jako płaszczyzna aktywności człowieka na przestrzeni dziejów podlegała ciągłym zmianom. Okresy istnienia społeczeństw przedprzemysłowych i przemysłowych były czasem gwarancji bezpieczeństwa i stabilności pracy oraz zatrudnienia dla większości pracowników posiadających różnorodne kompetencje i kwalifikacje. Obecnie zmora kruchości i niepewności ciągłości zatrudnienia nęka przedstawicieli wszystkich zawodów i profesji. Współcześnie żaden poziom wykształcenia, ani posiadany/wyuczony zawód nie daje pewności znalezienia pracy i jej utrzymania przez wiele lat. Poszczególne kategorie różnią się tylko tym, jakimi środkami jako zatrudnieni dysponują ludzie i jakie one dają im możliwości, w przeciwstawianiu się oraz reagowaniu na nową niestabilność i „ulotność” swoich usług i zmieniających się zobowiązań. Żadna grupa społeczna nie ma gwarancji, że nie utraci pracy, a jej umiejętności i kwalifikacje będą potrzebne i użyteczne. Nikt nie jest chroniony przed tym, co do niedawna nazywano długotrwałym bezrobociem. Związek pomiędzy stronami stosunku pracy nie jest symetryczny, zależność przestała być wzajemna. Z jednej strony mamy właścicieli kapitału, którzy poszukując pracowników, nie muszą już polegać na lokalnych rynkach pracy (mają bowiem do dyspozycji taki instrument jak chociażby outsourcing). Nie widzą zatem powodu, by miała im przyświecać jakakolwiek inna idea niż maksymalizacja zysku. Z drugiej strony mamy dwa rodzaje potencjalnych pracowników. Jedną grupę stanowią poszukujący pracy ludzie, którzy są, jak dawniej ,przywiązani do ziemi”, nie mają swobody ruchu, pozostają zależni od lokalnych miejsc pracy, dysponują niewielkimi umiejętnościami, ograniczoną wiedzą i doświadczeniem zawodowym. Inną kategorię stanowią ci, dla których przestrzeń niewiele znaczy, odległość nie stanowi kłopotu, to jednostki wielu miejsc, licznych umiejętności, zawodów i możliwości. Ta zobiektywizowana płynność statusu zatrudnienia znajduje swe dopełnienie w indywidualnych strategiach pracowników. Szczególnie obrazowo sytuację tę opisuje Z. Baumann pisząc, że współczesne miejsce zatrudnienia jest jak kemping, który odwiedza sięjedynie na kilka nocy i który można opuścić w każdym momencie, jeśli oferowane przezeń wygody nie sa zapewnione lub okaża się tych wymogów nie spetniać ${ }^{18}$.

\section{Bibliografia}

Bauman Z., The Individualized Society, Polity Press, Cambridge 2001.

Beck U., Spoleczeństwo ryzyka. W drodze do nowoczesności, Wydawnictwo Naukowe SCHOLAR, Warszawa 2004.

Clarke L., J. Short, Social organization and risk: some current controversies, „Annual Review of Sociology" 1993, vol. 19.

\footnotetext{
${ }^{18}$ Z. Bauman, The Individualized Society, Polity Press, Cambridge 2001, s. 25.
} 
Flexicurity Pathways. Turning hurdles into stepping stone, Report by the European Expert Group on Flexicurity, Brussels, June 2007.

Fukuyama F., Wielki wstrząs. Natura ludzka a odbudowa porządku społecznego, Bertelsman Media, Warszawa 2000.

Gableta M., Człowiek i praca w zmieniającym się przedsiębiorstwie, Wyd. Akademii Ekonomicznej im. Oskara Langego we Wrocławiu, Wrocław 2003.

Polacy pracujacy a kryzys fordyzmu, red. J. Gardawski, Wydawnictwo Naukowe SCHOLAR, Warszawa 2009.

Giddens A., Socjologia, WN PWN, Warszawa 2005.

Komisja Wspólnot Europejskich, Komunikat Komisji do Parlamentu Europejskiego, Rady Europejskiego Komitetu Ekonomiczno-Społecznego i Komitetu Regionów, Wspólne zasady wdrażania modelu Flexicurity, Bruksela 27.06.2007.

Reich R., Wystapienie na Międzynarodowej Konferencji Pracy w Genewie w 1994 [za:] M. Kabaj, Czy rynek pracy w Polsce jest mało elastyczny?, www.mg.gov.pl.

Schaff A., Rozważania na koniec wieku [w:] Człowiek i świat. Współczesne dylematy. Rozmowy Zdzisława Stowika, Biblioteka „Res Humana”, Warszawa 2007.

Stabryła A., Modelowanie elastycznych rozwiąań struktury organizacyjnej, „Zeszyty Naukowe Akademii Ekonomicznej w Krakowie" 1990, nr 323, Wyd. AE, Kraków.

Standing V.G., Prekariat. Nowa niebezpieczna klasa, PWN, Warszawa 2014. 